\title{
Orosz Ágnes
}

\section{Adósságválság és gazdasági kormányzás - utak és lehetőségek}

(Beszámoló az V. Gazdaságpolitikai Kerekasztal - Földobott kő? Tények és tendenciák a 21. században c. konferenciáról, Debrecen, 2011. április 15.)

A Debreceni Egyetem Közgazdaság- és Gazdaságtudományi Karának Közgazdaságtan Tanszéke, a Hajdú-Bihar Megyei Kereskedelmi és Iparkamara, valamint az MTA Debreceni Területi Bizottsága Jog- és Közgazdaságtudományi Szakbizottsága 2011. április 15-én gazdaságpolitikai konferenciát rendezett, amelynek a közgazdasági kar adott otthont. A 2007. évi, Egyesült Államokból kiinduló másodrendű jelzáloghitel-piaci válság mind a napig érezteti hatását, így a gazdaságpolitikai témájú viták, eszmecserék számára továbbra is témául szolgál. Az immár ötödik alkalommal megrendezett konferencia a „Földobott kő? - Tények és tendenciák a 21. században" címet viselte. Hat előadás hangzott el, amelyet kerekasztal-beszélgetés, vita követett.

Benczes István ${ }^{1}$ „Európai gazdasági kormányzás. Kihívások és kérdőjelek” címü előadása három jól elkülöníthető szakaszra oszlott. Elsőként a válság kezdetei és az erkölcsi kockázat beágyazódása, majd a válság és kormányzás, a kiútkeresési utak kerültek bemutatásra, végül pedig az ezekből fakadó kihívásokat és kérdőjeleket ismertette az előadó.

$\mathrm{Az}$ előadás egyik lényegi megállapítása szerint a Gazdasági és Monetáris Unió létrehozásával a kamatkonvergencia hatására puha költségvetési korlát alakult ki, így a tagországok esetében, a potyázás következtében az eladósodás teljesen racionális viselkedési normának tekinthető. Az előadó ezt a folyamatot határozta meg erkölcsi kockázatként. A GMU egyfajta kompromisszumként értelmezhetö, amelynek alapja a független jegybank, a konvergenciakritériumok, a ki-nem-mentési záradék és a Stabilitási és Növekedési Paktum.

$\mathrm{Az}$ előadás címében található európai gazdasági kormányzás teljesen új keletü fogalom, szükségességét a válság támasztja alá. Az új gazdasági kormányzás két pillére a válságrendezés és a válságmegelőzés. A korábban ismertetett erkölcsi kockázat hatására a prevenció nem müködött, és megnőtt a fertőzés veszélye. A válságkezelés alapjainak kidolgozásakor figyelembe kell venni, hogy a segítségnyújtás ne ütközzön alapszerződésbe, és az erkölcsi kockázatot se erősítse tovább, illetve a magánszektornak, az IMF-nek is nagyobb szerepet kell szánni, és a segítségnyújtást rendkívül szigorú feltételekhez kell kötni.

Orosz Ágnes??????????????????????????????????

${ }^{1}$ A Budapesti Corvinus Egyetem Közgazdaságtudományi Karának habilitált egyetemi docense 
A válságmegelőzés kapcsán az előadó kiemelte annak fontosságát, hogy a makrogazdasági egyensúlytalanságot és a versenyképességet is szükséges megvizsgálni², illetve kitüntetett szerepet kell kapnia a fiskális politikai koordinációnak és a fiskális fegyelemnek. Utóbbi elérésének eszköze az SNP erősítése, a kikényszeríthetőség javítása akár büntetésekkel, az államadósság figyelembe vétele a fenntarthatóságban, illetve az EU fiskális szabályainak nemzeti birtokbavétele.

Benczes felhívta a figyelmet, hogy nem mindegy, mit tekintünk egyáltalán erkölcsi kockázatnak. Amennyiben eltérő szinteken vizsgáljuk (bankok, tagállamok, befektetők), a kockázatvállalás eltérő motivációit találjuk, így megkérdőjelezhető, hogy valóban felelőtlenek voltak a tagállamok. Az is kérdéses, hogy minek a válsága következett be. Likviditási (bank) válság vagy szuverén (adósság) válság? Míg Görögország egy klasszikus fiskális válságra példa, addig Spanyolországban az ingatlanszektor problémái okozták az államadósság megugrását. Ami ma szuverén adósságválság, az tegnap még bankválság volt, így felvetődik a kérdés, nem lett volna-e szerencsésebb közösségi szinten fellépni a válság leküzdésére a bankok feltőkésítésével, mint hagyni, hogy minden tagország maga álljon helyt. A válság természete mellett arra sem adható egyértelmü válasz, hogy „ki fizesse a számlát” talány, hogy Görögország, ha a válságkezelés meg is történik valamilyen módon, hogyan lesz képes olyan növekedési ütemet produkálni, amellyel egyáltalán szinten tartható a jelenlegi adósságállomány, (GPD-arányosan 140\%), az államadósság csökkentéséről nem is beszélve. A korábbi gazdasági kormányzás mindenképpen fenntarthatatlan, mivel a „tagadás lehetetlen szentháromságára” épül: (1) nincs kilépés, (2) nincs nem-teljesítés és (3) nincs kimentés. A jelenlegi szabályozás az Európai Stabilitási Alap (a „nincs kimentés” szabályozás feloldása) és az adósságrendezés (a „nincs nem-teljesítés” követelmény enyhítése) előnyösnek tekinthető, mivel a válságrendezés terhei megoszlanak az adófizetők és a befektetők között. A továbbiakban elképzelhető, hogy lehetővé válik néhány ország számára a GMU elhagyása, ezáltal autonóm monetáris politika folytatása, önálló valuták bevezetése.

„Jogállam és gazdasági válság” című előadásában Győrffy Dóra az intézményrendszer, ezen belül a jogállamiság és a válság viszonyát mutatta be. Az előadás fö kérdése, hogy milyen hatást gyakorol a jogállamiság a gazdaság teljesítményére. A részletes elméleti megalapozást a bizonytalanság definiálása és az intézmények és bizonytalanság közötti kapcsolat feltárása követte. A formális és informális intézményeknek kell kijelölniük az emberek közötti kapcsolatok kereteit és lehatárolniuk az egyén választási lehetöségeit, így csökkentve a bizonytalanságot (North 1990). A szabályok működéséhez elengedhetetlen a kikényszerítés, azonban a szabálykövetés nem független a szabályok minőségétool. A jogállamiságot tekinthetjük a tartalmi politikai legitimáció meghatározó elemének. Tartalmi legitimáció híján a szabályok önkéntes követésére való hajlam alacsony. Ha a kikényszerítés költségei magasak, önkéntes jogkövetés hiányában a jogkerülő magatartás válik elterjedtté, ami növeli a jövővel kapcsolatos bizonytalanságot, és lerövidíti a döntések időhorizontját. A szabályszegés elterjedtsége és az intézmények megbízhatatlansága ördögi kört alkot, a magas

\footnotetext{
${ }^{2}$ Ennek eszköze lehet a szerkezeti torzulások figyelembe vétele, a túlzott egyensúlytalansági eljárás, illetve az Euró-plusz paktum.

${ }^{3}$ Megoldási javaslatként felmerülhet az adósságleírás, monetáris alap létrehozása, "bail-in” (a befektető fizet) vagy "bail-out" (az adófizetö fizet).

4 A Pázmány Péter Katolikus Egyetem Bölcsésztudományi Karának habilitált egyetemi docense
} 
bizalmi környezet tovább erősíti a szabálykövetést, és megnöveli a tervezés időhorizontját, míg a bizalmatlanság a szabályszegést erősíti, és hozzájárul a rövid távú tervezéshez.

A jogállamiság alapvetően hatást gyakorol a gazdaságpolitikára, ezt a hatást Győrffy az Európai Unió új tagállamai eurózónához vezető útjának példáján keresztül szemléltette. Feltételezése szerint (1) a politikusok időhorizontja követi a választók döntéseinek időhorizontját - hosszú távú, előremutató döntések magas bizalmi környezetben várhatóak; (2) az EU-10 országokban az euró bevezetése képviseli a hosszú távú orientációt a gazdasági kalkulációk megkönnyítésével és a hitelesség biztosításával, rövid távon azonban a feltételek teljesítése népszerütlen lehet. Az előadó hipotézise szerint az euró bevezetése magas bizalmi szintü országokban valószínű, míg az alacsony bizalmi szintű országokban a rövid távú politikák térnyerése a jellemző. E hipotézis igazolásához a Világbank World Governance Indicators $^{5}(2009,1996)$ indexeit használta. A bemutatott indexek alapján, két kivételtől eltekintve, az elméletet jól szemlélteti az euróbevezetés állása. Három csoportba rendezhetők az országok: Az 1. csoportba tartoznak a már eurózóna-tagországok. E csoportban Szlovénia és Észtország a legmagasabb intézményi minőséggel rendelkező ország, és az elméletnek ellentmondó példa Szlovákia ${ }^{6}$, amely az EU-10 intézményiminőség-rangsorában a 8. helyen áll. A 2. csoportba a legalacsonyabb intézményi minőséggel rendelkező országok tartoznak, Bulgária, Lettország és Litvánia, amelyek a hitelesség biztosítása érdekében lemondanak az önálló monetáris politikáról ${ }^{7}$. A 3. csoport tagjai a lebegő árfolyamrendszerrel rendelkező országok (Magyarország, Csehország, Lengyelország, Románia). Ez a korábbi vezető csoport, ahol nem volt szükség arra, hogy „megkössék a kezüket”, viszont a költségvetési hiány miatt az eurót sem tudták bevezetni. Ebben a csoportban találhatjuk a második kivételnek tekinthető országot, Romániát, amely Bulgária után a második legrosszabb intézményi minőséggel rendelkezik, viszont az alacsony államadósság következtében itt nem volt szükség a valutatábla bevezetésére. Az előadó kiemelte, hogy az elemzés mind az esetek alacsony száma, mind az időtáv rövidsége és a nemzetközi pénzpiaci helyzet különlegessége (az 'aranykor') miatt csupán az elmélet szemléltetéseként értelmezhető, azonban így is levonhatóak következtetések. A cseh és a lengyel eset azt illusztrálja, hogy a komolyabb gazdaságpolitikai hibák elkerülése nagyobb reformok hiányában is segít a válságok megelőzésében. Továbbá a rögzített árfolyamot választó országok sikere, majd összeomlása azt mutatja, hogy nincsenek könnyü, technikai megoldások az általános intézményrendszerből fakadó kényszerek kezelésére. Végezetül pedig a szlovák és a magyar eset tanulsága, hogy nincs determináció, a politikai vezetés színvonala, illetve a külső körülmények egymásra hatása révén a vártnál nagyobb javulás, illetve romlás is lehetséges.

Végső megállapításaiban Győrffy Dóra a jogállamiság gazdaságra gyakorolt hatását akképpen határozza meg, hogy a válságra való hajlam kialakulásában a gyenge intézményrendszer, beleértve a jogállamiság gyengeségét, lényeges szerepet játszik, és a bizonytalanság növekedésével a szereplők döntéseinek időhorizontja lerövidül. A rövid időhorizont meghatározza a politikai döntéshozatalt is - a rövid távú politikák változatosak lehetnek, az eladósodástól kezdve a különféle érdekcsoportok megvásárlásáig. A közös pont, hogy egyiktől sem várható tartós fejlődés. A jogállamiság gyengítése Magyarországon

\footnotetext{
${ }^{5}$ Elérhetö: http://info.worldbank.org/governance/wgi/sc_country.asp

6 Győrffy Dóra Szlovákia esetében a bizalom és a gazdaságpolitika viszonyát részletesen elemzi A jelen a jövő múltja c. kötetben megjelent tanulmányában (Györffy 2009).

7 Az elöadó esetükben külön kiemelte, hogy ez a döntés utólag igazolhatóan hatalmas áldozat, mivel a sokkokat és az inflációt nem tudják kezelni, anélkül, hogy az euró-zóna biztonságát és az EKB végső hitelezői szerepét élvezhetnék.
} 
tovább erősíti az elmúlt évtizedek szabálykerülő 'kultúráját. A válságmegelőzés és növekedés elősegítésében a jogállam megerősítése és a pártatlan kormányzás fontos eszköz (lehetne), melyek révén a bizonytalanság csökkentésével minden szereplő számára lehetővé válna a hosszú távra szóló tervezés.

Muraközy László ${ }^{8}$ elöadása („Merre tart a modern állam?”) Európára fókuszálva kívánja bemutatni az állami szerepvállalás alakulását, különös tekintettel az 1992-2007-es időszakra vonatkozóan 9 . Ez az időszak azért érdemel kitüntetett figyelmet, mivel a kilencvenes években kezdődött a fordulat az állami szerepvállalásban, viszont jóval magasabb szintekről indult meg a mérséklődés, mint ami az 1973/74-es időszakban volt megfigyelhető. „A kilencvenes évek közepétől tartó évtizedben, a kormányok erőfeszítéseinek, valamint nem utolsósorban az igen dinamikus gazdasági növekedésnek köszönhetően sikerült az államháztartások súlyát csökkenteni” (Muraközy 2010:788), azonban jelentős különbségek alakultak ki Európa országai között. Mindez fokozódó belső demográfiai kihívás mellett, úgy hogy a nyugdíj, az egészségügy és az időskorú gondoskodás jövőbeni súlyának radikális emelkedése rajzolódik ki. Ebben az időszakban a nemzetközi környezet is jelentősen átalakult, összeomlott a szocializmus, a globalizáció egyre jobban kiteljesedik, amelynek hatása különösen erős és viharos a pénzügyi- és tőkepiacok területén. A nemzeti államok meggyengültek, viszont még mindig túl erősek szoros integrációhoz, és a fejlett országok egyre nagyobb versennyel néznek szembe (Ázsia, Latin-Amerika). A vizsgált időszak végén 2007-ben azt állapíthatjuk meg, hogy csak mérsékelt konszolidáció következett be, az államháztartási centralizáció továbbra is lényegesen magasabb, mint a hetvenes évek közepén, az államháztartási kiadások megrekedtek a GDP fele környékén, a békés időszak ellenére, az államadósság pedig GDP-arányosan 50-70\% körül mozog.

Az előadás fontos kérdése, hogy „számít-e a méret” az államháztartási kiadások területén. Természetesen a méret valamennyire számít, mivel az extrém kilengések megrendíthetik az adott ország stabilitását, viszont Európa vizsgálata esetén szem előtt kell tartani, hogy itt egy relatíve magasabb államháztartási centralizáció a jellemző, amelynek nem várható a csökkentése. Az előadó új megközelítést ajánl, ami túlmutat pusztán az állam méretének vizsgálatán, hiszen sok évtizedes tapasztalat bizonyítja, hogy egydimenziós elméletekkel nem magyarázható az állami szerepvállalás alakulása. A kiindulópont, hogy az európai vegyes gazdaságok jellegzetes különbségeket mutatnak az állam jellegét és nem feltétlen méretét illetően, a hasonló jellemzőkkel bíró országcsoportokat pedig többdimenziós megközelítésben kell vizsgálni. Muraközy László irodalmi párhuzammal élve alkalmazta George Orwell Állatfarmjának leegyszerüsített jelmondatát: „négy láb jó, két láb rossz!” Nem tartható tovább a „kis állam” jó, a „nagy állam” rossz közelítés. Az állam méreténél sokkal jobban számít az állam erőssége vagy gyengesége, az „optimális” méret, a teljesítmény, a hatékonyság, illetve a szabályozás minősége. Amikor azt értékeljük, hogy milyen az adott állam teljesítménye, nem egyszerüen az állam méretét kell megvizsgálni, hanem az intézményi működést, a formális és informális intézmények összhangját, a társadalmi beágyazottságot, az állam és piac szinergiáját, a makro- és mikroszféra kapcsolódását vagy a nemzetközi versenyképességet.

\footnotetext{
${ }^{8}$ A kormányzati kiadások súlyának hosszabb időtávon (1929/1933-tól kezdődően) történő elemzéséhez, a válságoknak ebben betöltött szerepének részletes vizsgálatához lásd: Muraközy (2010)

9 A kormányzati kiadások súlyának hosszabb időtávon (1929/1933-tól kezdődően) történő elemzéséhez, a válságoknak ebben betöltött szerepének részletes vizsgálatához lásd: Muraközy (2010)
} 
A kormányzás minőségének vizsgálatához Muraközy is a Világbank World Governance Indicators ${ }^{10}$ adatait hívta segítségül az európai és a volt szocialista országcsoportok vizsgálatához. A WGI értékek alapján az európai országcsoportok esetén a méret és a minőség között nincs igazán összefüggés. A kontinentális és az angolszász országok közel azonos értékeket mutatnak, annyi kivétellel, hogy utóbbiak esetében a szabályozás minősége jobbnak tekinthető. A skandináv államok egyértelmüen kiemelkednek, különösen jó értéket mutat a politikai stabilitás, korrupció és szólásszabadság, míg a déli államok mindegyik kategória esetében jelentősen alulmaradnak. A volt szocialista országok közül a visegrádi és balti országok is közel hasonló teljesítményt mutatnak az összesített mutatót tekintve, de mintázatuk részben különbözik. A déli államok, Bulgária és Románia értékei rosszabbak minden területen, de meghaladják a FÁK-országokét, és összességében az európai FÁKállamok jobban teljesítenek, mint az ázsiaiak.

Az országok közötti különbségek vizsgálata szerint már a 2007-ben kirobbant válság elött is nagyon komoly kihívásokkal kellett megküzdenie ezeknek az országoknak, és országonként különböző ezeknek a kihívásoknak az erőssége és mintázata. Az előadó a továbbiakban olyan kihívásokat vázolt fel, amelyekkel a „Great Moderation” kedvező időszakában kellett (volna) együtt és külön-külön is szembenézniük az európai kormányzatoknak. Egyrészt a közszektor optimális méretének kiépítésével, mivel a nem optimális méret növekedési áldozattal jár. Ebben a tekintetben Európa országai nem tekinthetők optimálisnak, ellenben jelentős javulás következett be a skandináv államok, Németország és Ausztria esetében. Néhány ország 2007-ig még tovább távolodott az optimális szinttől, közéjük tartozik Írország, Portugália, az Egyesült Királyság és az Egyesült Államok. Kihívás továbbá a társadalom elöregedésének mélyülő folyamata. Az elöadásban képet kaptunk arról is, mi várható az egészségügyi és nyugdíjkiadások tekintetében 2050-ben, ha nem következik be jelentős fordulat. A felvázolt szcenárió alapján néhány országban ezek a kiadások a GDP 25\%-át is megközelíthetik. A harmadik kihívás Európa fokozódó térvesztése az erősödő és kiteljesedő globális versenyfutásban, ami jó tesztként szolgált a fiskális politikák számára. A globális versenyt a fiskális téren sikeresen teljesítők sokkal könnyebben vészelték át, mint a tőkepiac likviditási bőségében és az EU melegében megbújó „fiskális alkoholisták”. A 2007/2008-as válság hatására fentiek életre hívták a jelenleg is tapasztalható adósságválságot: példátlanul magas szintre ugrottak az államadósságok. Mind a négy probléma rendkívül erősen érinti Európát, és a következő évtizedekben ez tovább fokozódik. A fiskális fegyelem a korábbiaknál is hangsúlyosabb szerephez jut a jövőben, és az Európa országai közötti eltérések hosszú távon befolyásolják az esélyeket. A gazdaságpolitikáknak mindenképpen a gazdasági növekedést kell támogatniuk, mivel ilyen kihívások mellett a kiútkeresésben a kulcskérdés nyilvánvalóan a gazdasági növekedés üteme lesz.

Király Júlia ${ }^{11}$ „Válságmegelözés - új kísérletek” címü előadása követte az egy évvel korábbi előadásának fonalát, amelynek feltevése szerint húsz év múlva olyan fejlődési pályán mozog a magyar gazdaság, ahol fiskális fegyelem van, a toleráns, piacépítő, azt szabályozó, ám nem megrendszabályozó állam stabil, jól müködő tőkepiacot, versenyképes gazdaságot és fenntartható növekedést teremt ${ }^{12}$. E mostani előadás a pénzügyi közvetítőrendszer szerepét

\footnotetext{
10 Az összesített WGl-index 6 fö terület értékei alapján alakulhat ki: szólásszabadság, politikai stabilitás, kormányzati hatékonyság, a szabályozás minősége, törvényesség (rule of law), korrupció.

11 Címzetes egyetemi tanár, a Magyar Nemzeti Bank alelnöke

12 A témáról részletesebben lásd: Király Júlia (2011)
} 
vizsgálta: miképpen lehet rugalmas válságmegelőző intézményrendszert kiépíteni. A rugalmas inflációs célkövetés rendszere sarokköve a gazdasági stabilitás biztosításának, de szükséges az is, hogy a bankokat felügyelö intézményrendszer és a jegybank együttmüködjön a pénzügyi piacok felügyeletében. Magyarország azon kevés országok közé tartozik, ahol ez nem így alakult ki. A rugalmas keretek kialakításához szükséges a makroprudenciális politika, viszont nem egyértelmü, hogy mit kíván elérni, illetve nem vagy csak nehezen kvantifikálhatóak a céljai, hiszen már maga a pénzügyi stabilitás sem határozható meg egyértelmüen.

A pénzügyi rendszer bonyolult hálózat, egy-egy elemének időbeli alakulásáról sokat tudunk, viszont rendkívül keveset tudunk magáról a dinamikus hálózatról. Az elemzéséhez két dimenzió szükséges: egyrészt a keresztmetszeti dimenzió, amely a rendszer ellenállóképességének növelését jelenti, másrészt az időbeli dimenzió a prociklikusság mérséklésére. Olyan intézkedésekre van szükség, amelyek mindkét cél elérését támogatják. A problémák elörejelzésére vonatkozó ,„jelzőfények” és az alkalmazandó szabályok a prevenció fontosságát hangsúlyozzák. A makroprudenciális politika részeként olyan szabályokat kell alkotni, amelyek hozzájárulnak a válságok megelőzéséhez. A devizahitelezés problémáját klasszikus makroprudenciális problémaként vetette fel az előadó. Ennek érdekességét az adja, hogy minden szereplő (bankok, a hitelfelvevő, az állam) racionális döntést hozott, a problémát a rendszerszemlélet hiánya okozta. Ebben az esetben nem volt elegendö a kockázatokkal kapcsolatos figyelmeztetés. A jegybank, az illetékes minisztérium és a pénzügyi felügyelet együttes fellépésére lett volna szükség, bár a problémát megoldani ekkor sem lehetett volna, csak mérsékelni hatásait. Ebből levonható az a következtetés, hogy a devizahitelezés szabályozása nem lehet egy ország feladata, határon átnyúló makroprudenciális szabályozás szükséges. A globális szabályrendszer egy bank minden elemét érinti. Két célt igyekszik elérni, egyrészt növelni a bankok rendszerellenálló képességét (pl.: új bázeli likviditási mutatók), másrészt kontraciklikus szabályozást (pl.: új bázeli tőkeszabályozás) bevezetni.

Király Júlia a makroprudenciális politika fontosságának hangsúlyozása mellett azonban kiemelte, hogy a fiskális és monetáris politika, a mikroprudenciális és a szociális politika hatásait is figyelembe kell venni. A pénzügyi közvetítőrendszer jelenlegi bénultságának okaként fiskális politikai oldalról a bankadót, a makroprudenciális politika oldaláról a devizahitelezés betiltását, a mikroprudenciális politika esetében a 2. pillér alatti tőkekövetelmény növelését, a szociális politika tekintetében pedig a kilakoltatási moratóriumot emelte ki. Álláspontja alapján a fentebb említett problémák megoldása esetén lehet csak a jelenlegi magas jegybanki alapkamatot csökkenteni. Stabil, kiszámítható gazdaságpolitika szükséges, amely kellően képes a bizonytalanságot csökkenteni, csak ekkor várható a monetáris politikában kiszámítható kamatciklus.

Török Ádám ${ }^{13}$ „Az adósságválságok megelözésének intézményi feltételei”címü előadásának bevezetőjében azt hangsúlyozta, hogy az adósságválságok leküzdéséhez tartós megoldások szükségesek. A „nagy illúziók időszaka” véget ért a fejlett országokban, a 2007-2010-es válság a régi uniós tagállamokkal is megismertette a félelmet az adósságválságoktól. Már 2008-ban egyes új tagállamok, Magyarország, Lettország és Románia komoly likviditási vagy fizetőképességi gondokkal nézett szembe, szorult pénzügyi mentőcsomagra. 2010-ben pedig az ún. PIIGS ${ }^{14}$ országok, valamint bizonyos fokig az Egyesült Királyság és Belgium is

13 Akadémikus, a Pannon Egyetem és a BME professzora

${ }^{14}$ A mozaikszót Portugália, Írország, Olaszország, Görögország, valamint Spanyolország kezdőbetűi adják. 
bekerült az adósságválságok által fenyegetettek közé. Az előadás a problémát a nemzetközi pénzügyek, a jogi közgazdaságtan és a játékelmélet oldaláról igyekezett megvilágítani. A jogi közgazdaságtan elmélete alapján államadósság esetén központi probléma a szerződések kikényszeríthetősége. Az adósságrendezés jogi oldala számos nehézséggel bír, például a behajtás függ a nemzetközi jogtól, valamint a hitelezői érdekérvényesítés is eltérő. Török Ádám arra is felhívta a figyelmet, hogy az újabb kutatások szerint léteznek az államcsőddel egyenértékü rendezési megoldások, hiszen már nem csupán a fizetésképtelenség bejelentése tekinthető annak, hanem egy jelentősebb kockázatifelár-növekmény is. Az elhúzódó adósságválság legfóbb veszélyét az adósságszolgálat költségeinek folyamatos emelkedése jelenti, a gazdaság növekedési potenciáljának zsugorodásával egyidejüleg. A válsággal kapcsolatban az előadó külön kiemelte a kommunikáció szerepét. Jelenleg a befektetők nagyon érzékenyek bizonyos kifejezésekre, mint például az „adósságválság”, a „fizetésképtelenség” vagy az „államcsőd”. A magyar példa is azt igazolja, hogy az államcsőd kockázatainak objektív és szubjektív megítélése jelentősen eltérhet. Az államadósság belföldi kockázatának tekinthetjük a növekedési potenciál meggyengülését, a kormányzat hitelességének és az iránta való bizalomnak a megingását, valamint különösen nyitott gazdaságokban a fizikai és szellemi tőke kiáramlását. Nemzetközi kockázat továbbá a regionális befektetői klíma romlása, a fertőzés kockázatának növekedése, valamint „fekete lyukak" (állandóan súlyosan eladósodott országok) megjelenése.

2009-2010-et követően a fiskális fenntarthatóság kérdése kitüntetett szerepet kell kapjon, hiszen krónikussá, permanenssé válik az államadósság problémája, ami már nem csak eseti jellegü, mint korábban. A legtöbb OECD-ország adósságrátája a GDP 60 \%-a fölé kerül 2015-ig (Rogoff és Reinhardt 2010), ezért intézményi garanciák kellenek a probléma kordában tartásához. A fenntarthatóság egyik mérőszáma az implicit rés, ami a kamatszintek és a növekedés konzervatív elörejelzése alapján a jelenlegi elsődleges egyenleg és az adósságállomány stabilizálásához szükséges elsődleges egyenleg közötti különbség. Az adósságállomány hosszú távú stabilizálásának esélyei a PIIGS országokban (Olaszország részleges kivételével) és az Egyesült Államokban a legrosszabbak. Magyarország helyzete 2011 elején fenntartható szint közelében van, azonban ezt a piacok másképpen ítélik meg, mivel a politikai ciklusok erősen hatnak az államadósság alakulására ${ }^{15}$. Jogosan merül fel a kérdés, hogyan lehetne a fiskális politika ciklusérzékenységét megtörni. Ez is „időinkonzisztencia-probléma”, így a válasz itt is, akárcsak a monetáris politika esetén egy független intézmény létrehozása lehet. Mivel garantáltan nem politikai okok által vezérelve hozza meg a döntéseit, megtöri az időinkonzisztenciát. A fiskális politika esetében viszont mindenképpen szűkebb jogkörökre van szükség, hiszen az adósság szintje egy társadalmi értékválasztás eredményének is tekinthető, így egy ilyen intézmény nem rendelkezhet döntési jogkörrel.

Az előadó bemutatta, hogy az adósságpálya fenntarthatóságának megítélésében objektív és szubjektív tényezők egyaránt szerepet játszanak. A fenntarthatóság és a transzparencia összefügg egymással. Magyarország példa arra, hogy milyen rossz megitélés alá eshet egy ország (CDS-felár alapján 2011. januárban a 10 legkockázatosabb ország közé tartozott) annak ellenére, hogy az objektív mutatók szerint jól teljesít. A fiskális politika „intézményi horgonyára" van szükség minden olyan országban, ahol a befektetők kételkedhetnek a kormány teljes elkötelezettségében a fiskális fenntarthatóság és átláthatóság iránt. A

15 Ezt a jelenséget Kopits György „fiskális alkoholizmusként” határozta meg. 
piacokat megnyugtatóan és hosszabb távra meg kell győzni arról, hogy a fiskális politika az egyensúlyi célokat illetően teljesen független a politikai ciklusoktól. Török Ádám a független fiskális politikai intézmények feladatait és szerepét Kornai János 2010-ben tartott előadása alapján foglalta össze. Véleménye szerint az ilyen intézménynek a fiskális politikai döntések hatáselemzésével, a kormányzat gazdasági szerepének konzisztenciaelemzésével kell foglalkoznia úgy, hogy közben szigorúan ragaszkodik a transzparens fiskális politikához.

Tóth István György ${ }^{16}$ „Társadalomszerkezet és gazdaságpolitika: az állami védelem iránti kereslet meghatározói " című előadása a jövedelem-egyenlőtlenség szerepét vizsgálta a válság kialakulásában. Az állami beavatkozás iránti keresletet meghatározó tényezőket, valamint a magyar választók társadalmi összetételében bekövetkező változásokat tekintette át. A mediánszavazó elmélete alapján két feltételezésből indul ki, egyrészt a demokráciákban a redisztribúció nagyságát (és az adórátát) végső soron a szavazók döntik el, másrészt többségi szavazásra épülö reprezentatív demokráciákban az adóráta mértéke a mediánszavazó preferenciája szerint alakul.

Az egyenlőtlenség és a redisztribúció közötti közvetítő mechanizmusok, módosító tényezők lehetnek (1) az egyéni szintű érdekek, percepciók, értékek és attitűdök, (2) a makroszintü változók, azaz a politikai rendszer szereplői vagy a választási rendszer szabályai, illetve (3) a politikák egyenlőtlenséget formáló hatása az adók, támogatások, szabályozások révén. Tóth István György szerint a redisztribúció iránti egyéni szintü keresletet alapjaiban az egyéni önérdek határozza meg, $s$ a rosszabb anyagi helyzet lényegesen nagyobb redisztribúciós éhséggel párosul, az anyagi helyzet rosszabbodására számítók pozitívabban értékelik az állami újraelosztást. Azok, akik szerint a szegények maguk tehetnek a bajukról, kisebb mértékben szeretik az újraelosztást, viszont azok, akik szerint a szegénységnek társadalmi okai vannak, nagyobb keresletet mutatnak az állami újraelosztás iránt, a nagyobb fokú szegénység- és társadalmi feszültség-percepció erőteljesebb újraelosztás-pártisággal jár.

A kutatás eredményeit az előadó négy pontban foglalta össze ${ }^{17}$. (1) Az egyenlötlenségek szintjének országok közötti különbségei részben megmagyarázzák a redisztribúciós index országok közötti eltéréseit. (2) Nagyobb egyenlötlenségek nagyobb redisztributív igénnyel járnak együtt (az országok szintjén, átlagban). (3) Azokban az országokban, ahol az aggregált egyenlőtlenségek nagyobbak, a szegények, a középosztályok és a gazdagok redisztribuciós elvárásai is magasabbak (egyéb tényezők változatlansága mellett). (4) A gazdag-szegény attitüd-lejtő meredekebb a közepes egyenlőtlenségü országokban.

A magyar választók társadalmi összetételében a következő változások bekövetkeztét figyelték meg. Egyrészt a magyar társadalom (és a mediánszavazó) idősebb, kisebb háztartásokban él, és magasabb iskolázottságú, mint húsz éve. Másrészt ugyanebben az időszakban az idősebbek, kisebb háztartások és magasabb iskolázottságúak helyzete javult. Választóvonalat húz viszont a foglalkoztatottsági polarizáció (és az etnikai elkülönülés). Legvégül: az állami újraelosztás a status quo hatás révén is megteremti a saját keresletét a redisztribúció iránt.

A kerekasztal-vitát Martin József Péter vezette. A beszélgetés és a kérdések az előadások témájához kötődtek, és a válsággal kapcsolatos további kérdéseket járták körül. A Martin József Péter által feltett első kérdés („Miért viselte meg jobban az EU-t a válság, mint az

\footnotetext{
16 A TÁRKI Társadalomkutatási Intézet Zrt. vezérigazgatója, a Budapesti Corvinus Egyetem egyetemi magántanára

17 Erröl bővebben: Tóth - Keller (2011)
} 
USA-t?”) megosztotta az elöadókat. Muraközy László a történelem fontosságát hangsúlyozta az EU lemaradása esetén, valamint az eltérő attitüdök alapján hozott eltérő döntéseket, míg Győrffy Dóra a döntéshozatal lassúságát emelte ki.

A válságkezelés milyenségét firtató kérdések esetében Török Ádám hangsúlyozta, hogy a válságról még semmiképpen nem beszélhetünk múlt időben, mivel tartós megoldás érdekében „új iparosításra” van szükség, de még nem tudható, milyen ipar képes kialakulni ott, ahol korábban sem volt megfelelö ipar.

Îrország jelenlegi helyzete eléggé talányos, mivel magas bizalmi környezet, jó intézményrendszer jellemzi és nem voltak korábban költségvetési problémái. Ennek az ellentmondásnak a felfejtésére is vállalkoztak az előadók, ahol Győrffy Dóra az amerikai gyakorlat átvételének és kizárólagosságának problémáját ismertette, míg Török Ádám azt hangsúlyozta, hogy téves döntés volt az euró bevezetése az ő esetükben anélkül, hogy azt az Egyesült Királyság megtette volna.

A továbbiakban Magyarország euróhoz vezető útját vették górcső alá az előadók. Török Ádám kiemelte, hogy el kellene dönteniük a politikai döntéshozóknak, az euróbevezetés teremt-e hitelességet, vagy éppen a hitelesség teremti meg az euróbevezetés feltételeit. Tóth István György azt hangsúlyozta, hogy ma a válság következtében már nincs meg a korábbi egyetértés az euró egyértelmű előnyeivel kapcsolatban. Álláspontja szerint pénzügyi fegyelemre és fiskális kiegyensúlyozottságra eurótól függetlenül is szükség van. Benczes István felhívta a figyelmet, hogy a saját valuta használata sem jelent valódi autonómiát, mivel az ország nem tudja függetleníteni magát a nemzetközi intézményektöl.

A konferencia hozzásegítette a hallgatóságot a válság hatásainak jobb megértéséhez mind az Európai Unió, mind Magyarország vonatkozásában. A felvetett problémák sokaságából, a vitából, a nyitva maradt kérdésekből bízvást következtethetünk arra, hogy jövő tavasszal sem lesz hiány a megvitatandó témákból.

\section{Irodalomjegyzék}

Győrffy Dóra (2009): Gazdaságpolitika bizalom nélkül. Megjelent: Muraközy László (szerk.) (2009): A jelen a jövő múltja. Járt utak - járatlan úttalanságok. Akadémiai Kiadó, 162-194. o.

Király Júlia (2011): 20 év múlva. (képzeletbeli előadás 2030 áprilisából). Megjelent: Muraközy László (szerk.) (2011): 20 év múlva - Vissza a jövőbe. Akadémiai Kiadó, 41-69. o.

Kornai János (2010): Bevezető megjegyzések. 2010. március 18-19. Conference on Independent Fiscal Institutions. Budapest

Muraközy László (2010): Válságok állama - államok válsága. Közgazdasági Szemle, 57. évf., 9. szám 779797. o.

North, D. C. (1990): Institutions, Institutional Change and Economic Performance. Cambridge University Press, Cambridge

Reinhardt, C. M. - Rogoff, K. S. (2010): This Time Is Different: Eight Centuries of Financial Folly. Princeton University Press, Princeton, NJ

Tóth István György - Keller Tamás (2011): Income distributions, inequality perceptions and redistributive claims in European societies. Amsterdam, AIAS, GINI Discussion Paper 7. 